\title{
Thermal Conductivity of Zinc Oxide Micro- and Nanocomposites
}

\author{
B.I. Turko ${ }^{1, *}$, V.B. Kapustianyk ${ }^{1,2}$, V.P. Rudyk ${ }^{1}$, Y.V. Rudyk ${ }^{2}$ \\ 1 Scientific-Technical and Educational Center of Low Temperature Studies, 50, Drahomanova St., 79005 Lviv, \\ Ukraine \\ ${ }^{2}$ Department of Physics, Ivan Franko National University of Lviv, 50, Drahomanova St., 79005 Lviv, Ukraine
}

(Received 21 January 2016; revised manuscript received 09 June 2016; published online 21 June 2016)

\begin{abstract}
The thermal conductivity of the composite materials based on the zinc oxide powders with different average particle sizes (micrometer, submicrometer and nanometer) dispersed in the polymethylsiloxane (silicone oil) was measured using the radial heat flow method. The thermal conductivity of the composite material based on the commercial $\mathrm{ZnO}$ micropowder with an average particle size of $50 \mu \mathrm{m}$ was found to be $0.8 \mathrm{~W} /(\mathrm{m} \cdot \mathrm{K})$. The thermal conductivity of the composite material on the basis of $\mathrm{ZnO}$ nanopowder with an average particle size of approximately $3 \mathrm{~nm}$ synthesized using the wet chemistry methods was found to be $2.5 \mathrm{~W} /(\mathrm{m} \cdot \mathrm{K})$. The discovered enhancement of the above mentioned parameter is considered as manifestation of the quantum size effects in heat transfer.
\end{abstract}

Keywords: Zinc Oxide, Nanocomposites, Thermal Transport.

DOI: 10.21272/jnep.8(2).02004

PACS numbers: 44.10. + i, 81.05.Qk

\section{INTRODUCTION}

Due to continuous improvement and development of nanotechnology the size of electronic integrated circuits is rapidly approaching the maximally allowable by the quantum size effects limits of $10 \mathrm{~nm}$. It is expected, that they will be achieved by 2018 [1]. The integrated circuits of such a small size have to be effectively cooled to prevent their thermal breakdown.

For a long time the $\mathrm{ZnO}$ micropowders are successfully and widely used as one of the main components at manufacturing of various low-cost, commercial thermal greases. The value of the thermal conductivity coefficient of these greases is in the range from 0.6 to $1.5 \mathrm{~W} /(\mathrm{m} \cdot \mathrm{K})$. At the same time, the number of publications concerning the thermal conductivity of the nanostructured materials based on $\mathrm{ZnO}$ is limited [2,3]. The majority of these works are devoted to investigations of the single crystals [4,5], ceramics [2] or thin films $[6,7]$. This work presents the data concerning dependence of the thermal conductivity of composite materials based on zinc oxide and polymer polymethylsiloxane (silicone oil) on the average $\mathrm{ZnO}$ particle size in order to detect manifestation of quantum size effects in heat transfer.

\section{EXPERIMENTAL}

The composite materials were produced by dispersing of $\mathrm{ZnO}$ micropowder with an average particle size of $50 \mu \mathrm{m}(99.7 \%$, UKRZINC, Kyiv, Ukraine), or submicropowder $\mathrm{ZnO}$ (99.9\%, Sigma-Aldrich, Steinheim, Germany) with particle size less than $1 \mu \mathrm{m}$ or specially created $\mathrm{ZnO}$ nanopowder with an average particle size of about $3 \mathrm{~nm}$ in the polymethylsiloxane PMS 1000 (silicone oil, SOFEX, Moscow, Russia). The silicone oil and the fillers - $\mathrm{ZnO}$ powders were taken in a volume ratio of $3: 7$.

$\mathrm{ZnO}$ nanopowder was synthesized by the "wet chemistry" methods in an aqueous solution of $0.016 \mathrm{~mol}$ of zinc acetate dihydrate $\left(98 \%, \mathrm{Zn}\left(\mathrm{CH}_{3} \mathrm{COO}\right)_{2} \cdot 2 \mathrm{H}_{2} \mathrm{O}\right.$, Sigma-Aldrich, Steinheim, Germany) and $0.095 \mathrm{~mol}$ of aqueous ammonia $\left(99.9 \%, \mathrm{NH}_{4} \mathrm{OH}\right.$, Sigma-Aldrich, Steinheim, Germany) at the temperature $95{ }^{\circ} \mathrm{C}$ [8]. The growing was carried out for 10 minutes. Then the solution was dried in air.

The formation of the zinc oxide nanostructures may be described by the following reactions [9]:

$$
\begin{aligned}
& \mathrm{Zn}\left(\mathrm{CH}_{3} \mathrm{COO}\right)_{2}+4 \mathrm{NH}_{4} \mathrm{OH}= \\
& =\left(\mathrm{NH}_{4}\right)_{2} \mathrm{ZnO}_{2}+2 \mathrm{CH}_{3} \mathrm{COONH}_{4}+2 \mathrm{H}_{2} \mathrm{O} \\
& \left(\mathrm{NH}_{4}\right)_{2} \mathrm{ZnO}_{2}+\mathrm{H}_{2} \mathrm{O}=\mathrm{ZnO}+2 \mathrm{NH}_{4} \mathrm{OH} .
\end{aligned}
$$

Determination of the thermal conductivity of the composites was carried out by radial heat flow method [10]. For this purpose the measuring cell with a thickwalled copper cylinder, whose ends were closed by the insulating lids, was created. Along the axis of the cylinder fully filled with a composite, there was placed a heater creating a temperature gradient in the radial direction. In order to limit the temperature field perturbation by the values of 3-5\%, the ratio of the cylindrical composite layer length $l$ to its diameter $d$ was selected to be equal approximately $l / d \approx 4$ [10]. The temperature gradient was measured by the two thermocouples located along the radius (Fig. 1).

The coefficient of thermal conductivity $a(\mathrm{~W} /(\mathrm{m} \cdot \mathrm{K}))$ was calculated on the basis of the following relation:

$$
\alpha=K \frac{\ln \left(r_{2} / r_{1}\right)}{2 \pi l\left(T_{1}-T_{2}\right)} U I,
$$

where $K-$ is the factor of the axial heat loss through the plugs of the measuring cell (depends on the plug material and is calculated by reference to a sample with known thermal conductivity); $r_{1}$ and $r_{2}-$ the inner and outer radii of the cylindrical composite layer; $T_{1}$ and $T_{2}$ - the temperatures of the internal and external surfaces

\footnotetext{
*tyrko_borys@ukr.net
} 
of the composite layers; $l$ - the length of the cylindrical composite layer; $U$ - the voltage on the heater; $I-$ the current in a heater.

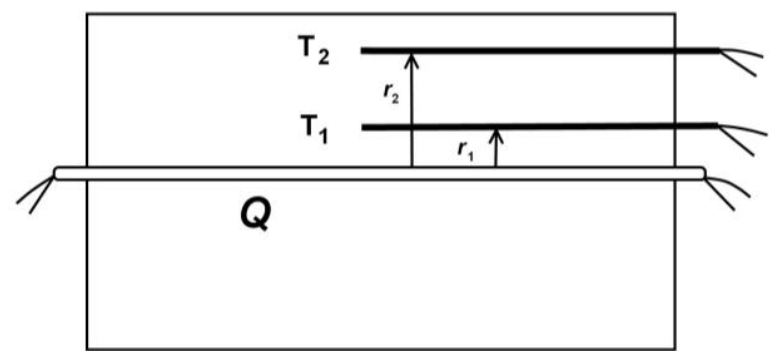

Fig. 1 - The scheme of the measuring cell: $Q$ - heater; $T_{1}$ and $T_{2}$ - thermocouples

The optical absorption spectra were measured at room temperature using Specord M-40 computerized spectrophotometer (Germany).

\section{RESULTS AND DISCUSSION}

The absorption spectrum of the nanocomposite thin layer at room temperature is depicted in Fig. 2. In the second spectrum can clearly observe the $\mathrm{ZnO}$ exciton absorption band with a maximum at $\lambda_{p}=358 \mathrm{~nm}$.

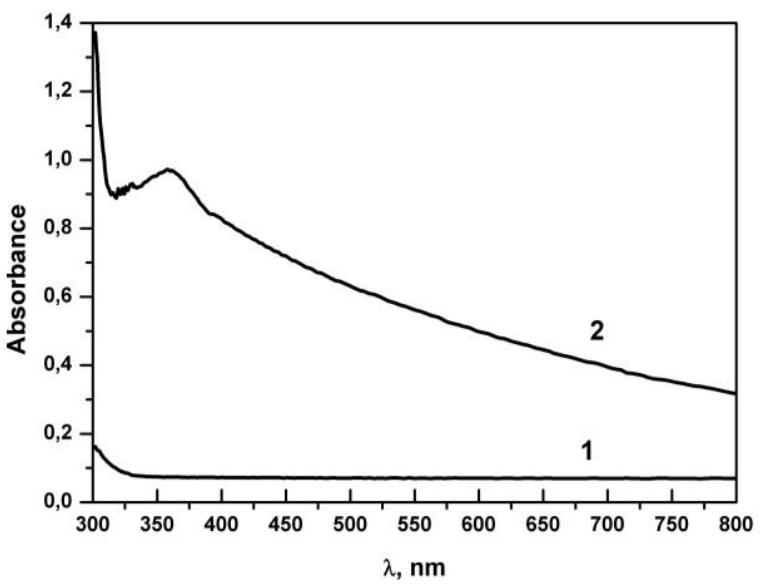

Fig. 2-The room temperature absorption spectra of: 1 . polymethylsiloxane layer with a thickness of approximately $100 \mu \mathrm{m}, 2$ - nanocomposite layer with a thickness less than $1 \mu \mathrm{m}$

In order to determine the radius $R$ of $\mathrm{ZnO}$ nanoparticles in the composite one can use the equation [11]:

$$
R(n m)=\frac{\sqrt{-26.23012+\frac{10240.72}{\lambda_{p}(n m)}}}{-6.3829+\frac{2483.2}{\lambda_{p}(n m)}}
$$

The average radius of $\mathrm{ZnO}$ nanoparticles was found to be equal approximately $3 \mathrm{~nm}$. The values of the thermal conductivity of the composite materials based on zinc oxide powders with a grain size of $50 \mu \mathrm{m}$, less than $1 \mu \mathrm{m}$ and about $3 \mathrm{~nm}$, calculated according to the equation (3), were found to be equal to $0.8 \mathrm{~W} /(\mathrm{m} \cdot \mathrm{K})$, $1.1 \mathrm{~W} /(\mathrm{m} \cdot \mathrm{K})$ and $2.5 \mathrm{~W} /(\mathrm{m} \cdot \mathrm{K})$ respectively. The relative measurement error did not exceed $10 \%$.

The thermal conductivity of the polymethylsiloxane is known to be equal $a=0.15 \mathrm{~W} /(\mathrm{m} \cdot \mathrm{K})$ at room temperature [12]. Besides, it is known [4, 5, 13], that the coefficient of thermal conductivity of $\mathrm{ZnO}$ single crystals is in the range from $100 \mathrm{~W} /(\mathrm{m} \cdot \mathrm{K})$ up to $120 \mathrm{~W} /(\mathrm{m} \cdot \mathrm{K})$ and depends on the manufacturing technology and processing samples.

The heat transfer in the semiconductors is described by [14]:

$$
a=a_{\mathrm{ph}}+a_{\mathrm{e}}+\alpha_{\mathrm{bp}}+a_{\mathrm{phot}}+a_{\mathrm{ex}}
$$

where $a_{\mathrm{ph}}$ - is the phonon thermal conductivity (heat transfer caused by thermal vibrations of atoms in the crystalline lattice); $a_{\mathrm{e}}$ - the electron/hole conductivity (heat transfer caused by free charge carriers); $a_{\mathrm{bp}}-$ the bipolar conductivity due to the motion of the electron-hole pairs in the intrinsic conductivity; $a_{\text {phot }}$ - the photon thermal conductivity due to the heat transfer by electromagnetic radiation; $a_{\mathrm{ex}}-$ the exciton conductivity caused by the exciton motion.

The phonon thermal conductivity is described by the equation:

$$
a_{\mathrm{ph}}=C \cdot v \cdot l / 3=C_{\mathrm{v}} \cdot \rho \cdot v \cdot l / 3,
$$

where $C$ - is the heat capacity, $C_{\mathrm{v}}$ - the specific heat capacity at a constant volume, $\rho$ - the material density, $v-$ the average speed of phonons, $l$ - the average phonon mean free path.

The temperature dependence of the phonon thermal conductivity manifests a maximum at the temperature close to $0.1 T_{\mathrm{D}}$, where $T_{\mathrm{D}}-$ is a Debye temperature (370 $\mathrm{K}$ for $\mathrm{ZnO}$ [15]).

The thermal conductivity is connected with the electronic conductivity $\sigma$ by the Wiedemann-Franz law:

$$
a_{\mathrm{e}}=L \cdot \sigma T,
$$

where $T$ - is a temperature, $L$ - the Lorentz number, which for a non-degenerate semiconductors is determined from the equation:

$$
L=(s+2)(k / e)^{2},
$$

where $s-$ is the scattering parameter; $k$ - the Boltzmann constant; $e-$ the electron charge.

The bipolar thermal conductivity arises due to the proper electrical conductivity of the semiconductor materials. The number of electrons and holes on the hot end of the semiconductor is larger than those on the cold end, and this causes diffusion of the electron-hole pairs from the hot end to the cold one. On the hot end the energy, necessary to form such a pair, is absorbed, whereas on the cold one - the energy is released due to the recombination of electron-hole pairs. This energy consists not only from the kinetic energy of the electrons and holes, but also from the energy which is required to move an electron from the valence band into the conduction band. The latter is equal to the band gap energy $E_{\mathrm{g}}$. For the semiconductors usually $E_{\mathrm{g}}>k T$. Therefore, the energy carried by the electronhole pair is much higher than those carried by each of the carriers in the case of the impurity conductivity. In the case of a proper electrical conductivity there arises an additional heat flux (i.e. additional thermal conductivity $a_{\mathrm{bp}}$ ) due to the bipolar diffusion. It is clear that 
the bipolar thermal conductivity depends on the concentration of the electron-hole pairs and the band gap.

For the bipolar thermal conductivity one can use the same relation as for the case of the electronic thermal conductivity:

$$
a_{\mathrm{bp}}=L_{\mathrm{bp}} \cdot \sigma \cdot T,
$$

where $L_{\mathrm{bp}}$ - is the analogue of the Lorentz number, but for a bipolar thermal conductivity.

The photon thermal conductivity is relevant for the semiconductors with a low enough absorption coefficient in the region of thermal radiation. In this case the photons are characterized by a large mean free path, and it is necessary to take into account the contribution of the heat transfer due to the electromagnetic radiation.

The photon thermal conductivity aphot can be estimated using the Genzel's relation [16]:

$$
a_{\text {phot }}=16 / 3 \cdot n^{2} \cdot \sigma 0 \cdot T^{3 / k},
$$

where $n$-is the refractive index, $\sigma_{0}$-StefanBoltzmann constant, $k$ - the absorption coefficient.

The exciton thermal conductivity is caused by diffusion of excitons due to the temperature gradient. It becomes important when the conditions of excitons generation are realized in a semiconductor.

The exciton binding energy $E_{\text {ex }}$ for the quantum dots with a size a little larger than the exciton Bohr radius is described by the equation [17]:

$$
E_{e x}=\frac{\left(m_{e} m_{h}\right) \pi^{2} a_{B}^{2} R_{e x}^{3 D}}{\left(m_{e}+m_{h}\right)^{2} a^{2}},
$$

where $R_{e x}^{3 D}$ - is the exciton binding energy in the bulk sample; $m_{e}$ - effective electron mass; $m_{h}$ - effective hole mass; $a$ - the size of the quantum dot; $a_{B}-$ the exciton Bohr radius.

It is also necessary to draw attention to some specific features of heat transfer in the nanostructures such as ballistic conductivity and reducing of the thermal contact resistance [18].

In the case when the mean free path of carriers or quasiparticles is larger than the typical sample size the ballistic thermal conductivity is realized and heat is transferred without collisions. The thermal resistance of a sample in this case is equal to zero.

It is also necessary to consider the contact thermal resistance or Kapitza resistance - namely the thermal resistance at the boundaries of the two bodies contact. The I. M. Khalatnikov proposed the theoretical work allowing evaluation of the thermal contact resistance. In his model the surface of the contact interface is considered as a flat infinitely thin boundary between the two materials. Depending on the properties of these materials there occurs refraction or reflection of phonons on the both sides of the boundary. The difference between the phonon energy flows from the material with a higher temperature to the material with a lower temperature and back determines the relation between the flow and the temperature jump on the interface:

$$
q=\Delta T / h_{\mathrm{K}},
$$

where $q$ - is the heat flow through the interface; $\Delta T$ temperature difference at the interface; $h_{\mathrm{K}}$ - Kapitza resistance.

In spite of the widely spread application of these ideas, Khalatnikov model is highly idealized and implies a quite large error. The model does not consider the surface roughness, possibility of mutual diffusion of the two materials, quantum size effects, energy release directly on the interface at phonons scattering and so on. Nevertheless, the equation (12) in many cases is acceptable. Under such circumstances the experimental studies of Kapitza resistance changes depending on the type of material, temperature, manufacturing technology of the contacts and other conditions are of great importance.

Recently, many researches are devoted to minimization of Kapitza resistance - creating of the highly heat-conducting layers at the borders between the two substances using special thermal interface materials. Using the nanoparticles as the components of such layers it is possible to provide extremely full contact between the adjacent rough surfaces. By such a way one can obtain the maximum contact area, contrary to the case of the microparticles contact with a rough surface.

In our case, increasing of the thermal conductivity of the thermal compound based on the $\mathrm{ZnO}$ nanopowder instead of $\mathrm{ZnO}$ micropowder may be considered as manifestation of the quantum size effect. Since the particle sizes in the nanopowder $(\sim 3 \mathrm{~nm})$ is commensurate with the exciton Bohr radius ( $2 \mathrm{~nm})$ [19], that is significantly lower than the mean free path of phonons $(\sim 30 \mathrm{~nm})$ [20] and the de Broglie wavelength in $\mathrm{ZnO}$ $(14 \mathrm{~nm})$ [21], it is convenient to consider the ballistic mechanism of the heat conductivity. The free excitons in zinc oxide are stable even at room temperature due to their large binding energy $(60 \mathrm{meV})$ [22]. Therefore, in the nanocomposite material on the basis of $\mathrm{ZnO}$ the exciton component of thermal conductivity could also be significant.

\section{CONCLUSION}

The coefficients of thermal conductivity of the composite materials based on the zinc oxide powders with a different grain size $-50 \mu \mathrm{m}$, less than $1 \mu \mathrm{m}$ and about $3 \mathrm{~nm}$ were determined by radial heat flow method. They were found to be equal to $0.8 \mathrm{~W} /(\mathrm{m} \cdot \mathrm{K}), 1.1 \mathrm{~W} /(\mathrm{m} \cdot \mathrm{K})$ and $2.5 \mathrm{~W} /(\mathrm{m} \cdot \mathrm{K})$ respectively. The observed clear increase of the thermal conductivity of the thermal compound based on $\mathrm{ZnO}$ nanopowder instead of $\mathrm{ZnO}$ micropowder is explained by the ballistic conductivity, increasing of the exciton thermal conductivity and reduction of the contact thermal resistance.

\section{AKNOWLEDGEMENTS}

This work was supported by Ministry of Education and Science of Ukraine. 


\title{
Теплопроводность микро- и нанокомпозитов на основе оксида цинка
}

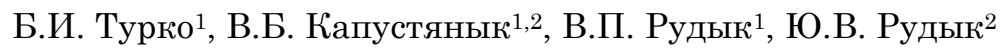

${ }^{1}$ Научно-технический и образовательный иентр низкотелпературных исследований, ул. Драгоманова, 50, 79005 Львов, Украина

2 Львовский национальный университет илени Ивана Франка, фбизический фбакультет, ул. Драголанова, 50, 79005 Львов, Украина

\begin{abstract}
Методом радиального теплового потока измерены значения коэффициентов теплопроводности композитных материалов на основе порошков оксида цинка с различными средними размерами частиц (микронных, субмикронных и нанометровых) и полиметилсилоксана (силиконового масла). Коәффициент теплопроводности композитного материала на основе коммерческого микропорошка $\mathrm{ZnO}$ со средним размером частиц 50 мкм оказался равным $0,8 \mathrm{BT} /(\mathrm{м} \cdot \mathrm{K})$. Коэффициент теплопроводности композитного материала на основе нанопорошка $\mathrm{ZnO}$ со средним размером частиц около 3 нм, синтезированного методом «мокрой химии», оказался равным 2,5 Вт/(м·K). Обнаруженное повышение указанного параметра рассматривается как проявление квантово-размерных эффектов в передаче тепла.
\end{abstract}

Ключевые слова: Оксид Цинка, Нанокомпозиты, Теплоперенос.

\section{Теплопровідність мікро- і нанокомпозитів на основі оксиду цинку}

\author{
Б.І. Турко ${ }^{1}$, В.Б. Капустяник ${ }^{1,2}$, В.П. Рудик ${ }^{1}$, Ю.В. Рудик ${ }^{2}$ \\ ${ }^{1}$ Науково-технічний $і$ навчальний центр низькотелпературних досліджень, вул. Драголанова, 50, 79005 \\ Львів, Україна \\ 2 Львівський національний університет ілені Івана Франка, ббізичний фбакультет, вул. Драголанова, 50, \\ 79005 Львів, Україна
}

\begin{abstract}
Методом радіального теплового потоку виміряно значення коефіщієнтів теплопровідності композитних матеріалів на основі порошків оксиду цинку з різними середніми розмірами частинок (мікронних, субмікронних і нанометрових) та поліметилсилоксану (силіконового масла). Коефіщіент теплопровідності композитного материалу на основі комерційного мікропорошку $\mathrm{ZnO}$ зі середнім розміром частинок 50 мкм виявився рівним $0,8 \mathrm{BT} /(\mathrm{m} \cdot \mathrm{K})$. Коефіціент теплопровідності композитного матеріалу на основі нанопорошку $\mathrm{ZnO}$ зі середнім розміром частинок приблизно 3 нм, який було синтезовано методом «мокрої хімії», виявився рівним $2,5 \mathrm{BT} /(\mathrm{м} \cdot \mathrm{K})$. Виявлене зростання вказаного параметру розглядаеться як прояв квантово-розмірних ефектів у переносі тепла.
\end{abstract}

Ключові слова: Оксид Цинку, Нанокомпозити, Теплопереніс.

\section{REFERENCES}

1. Chips 2020: A Guide to the Future of Nanoelectronics (Ed. B. Hoefflinger) (Berlin: Springer-Verlag: 2012).

2. T. Olorunyolemi, A. Birnboim, Y. Carmel, O. Wilson, I.K. Lloyd, S. Smith, R. Campbell, J. Am. Ceram. Soc. 85, 1249 (2002).

3. K.T. Igamberdiev, S.U. Yuldashev, H.D. Cho, T.W. Kang, S.M. Rakhimova, Phys. Solid State 54, 1514 (2012).

4. U. Ozgur, X. Gu, S. Chevtchenko, J. Spradlin, S. Cho, H. Morkoc, F.H. Pollak, H.O. Everitt, B. Nemeth, J.E. Nause, J. Electron. Mater. 35, 550 (2006).

5. D.I. Florescu, L.G. Mourikh, F.H. Pollak, D.C. Look, G. Cantwell, X. Li, J. Appl. Phys. 91, 890 (2002).

6. Z.X. Huang, Z.A. Tang, J. Yu, S. Bai, Physica B 406, 818 (2011).

7. Y. Xu, M. Goto, R. Kato, Y. Tanaka, Y. Kagawa, J. Appl. Phys. 111, 084320 (2012).

8. H.Q. Le, S.J. Chua, Y.W. Koh, K.P. Loh, Z. Chen, C.V. Thompson, E.A. Fitzgerald, Appl. Phys. Lett. 87, 101908 (2005).

9. P. Mitra, S. Mondal, Progr. Theor. Appl. Phys. 1, 17 (2013).

10. M.O. Haluschak, V.G. Ralchenko, A.I. Tkachuk, D.M. Freik, Phys. Chem. Solid State 14, 317 (2013).

11. S. Samuel, L. Bose, Acad. Rev. 16, 57 (2009).
12. B. Kolade, K.E. Goodson, J.K. Eaton, J. Heat Transf. 131, 052402 (2009).

13. C.F. Klingshirn, A. Waag, A. Hoffmann, J. Geurts, Zinc Oxide: From Fundamental Properties Towards Novel Applications (Berlin: Springer-Verlag: 2010).

14. Y.M. Poplavko, Electrophysics of Solids States: Tutorial (Kyiv: KPI: 2012).

15. X. Liang, M. Baram, D.R. Clarke, Appl. Phys. Lett. 102, 223903 (2013)

16. M. Faucher, F. Cabannes, A.M. Anthony, B. Piriou, J. Simonato, J. Am. Ceram. Soc. 58, 368 (1975).

17. S.V. Gaponenko, Phys. Tech. Semicond. 30, 577 (1996).

18. V.I. Khvesyuk, Eng. J.: Sci. Innov. 5, 1 (2013).

19. V. Kapustianyk, M. Panasiuk, G. Lubochkova, B. Turko, V. Rudyk，M. Partyka，R. Serkiz，D. Voznyuk，J. Phys. Stud. 12, 2602 (2008).

20. D. Gautam, M. Engenhorst, C. Schilling, G. Schierning, R. Schmechel, M. Winterer, J. Mater. Chem. A 3, 189 (2015).

21. V.P. Gavrilenko, Int. Rev. Atom. Mol. Phys. 4, 1 (2013).

22. V. Kapustianyk, B. Turko, Y. Rudyk, V. Tsybulskyi, V. Rudyk, A. Vaskiv, Phys. Surf. Eng. 13, 169 (2015). 